Article

\title{
Evaluating Supplier Management Maturity in Prefabricated Construction Project-Survey Analysis in China
}

\author{
Kangning Liu ${ }^{1}$, Yikun Su ${ }^{2}$ and Shoujian Zhang ${ }^{1, *(1)}$ \\ 1 School of Civil Engineering, Harbin Institute of Technology, Harbin 150001, China; corninghit@163.com \\ 2 School of Civil Engineering, Northeast Forestry University, Harbin 150040, China; suyikun@nefu.edu.cn \\ * Correspondence: zhangsj@hit.edu.cn; Tel.: +86-451-8620-5848
}

Received: 26 July 2018; Accepted: 23 August 2018; Published: 27 August 2018

check for updates

\begin{abstract}
Prefabrication is considered as a modern method of construction, transferring part of on-site work into factories and generating a new decoupling point in supply chain. Management of prefabricated component (PC) suppliers plays a key role in the performance of prefabricated construction project (PCP). Evaluating and improving supplier management maturity (SMM) become critical issues for large contractors. Previous research on PCP supply chain mainly focused on technology, process and performance aspects, while paying little attention to supplier relationship management. This study proposes an assessment criteria system of supplier management from five dimensions, including procurement process, operation efficiency, relationship coordination and strategy alignment and corporate social responsibility. A maturity grid with five levels is designed to present continuous improvement of supplier management. 34 large PCP construction firms listed in contractor directory were investigated in China through semi-structured interview and questionnaire survey. Independent two-samples $t$-test and one-way analysis of variance were adopted to explore SMM of different groups according to business scope, procurement method and construction experience. The results indicate that the overall maturity level of supplier management is relatively low, implying that supply activity cannot achieve inter-organization integration. Management on relationship coordination and strategy alignment lag behind procurement management and operation efficiency. Single business contractors have higher SMM than diversified ones. Contractors integrated in engineering, procurement and construction are superior to design-bid-build contractors in supplier management, especially in relationship coordination and strategic alignment. Construction experience is conductive to supplier operation efficiency. Noticeably, there are no statistically significant differences in the performance of corporate social responsibility among different groups. These results will contribute to developing a benchmark framework for contractors to evaluate SMM and achieve continuous improvements in PCP.
\end{abstract}

Keywords: supplier management; maturity model; prefabricated construction project; EPC; corporate social responsibility

\section{Introduction}

Prefabrication, is also known as off-site construction, modular construction and modern method of construction, transferring part of on-site work into factory which provides a controlled manufacturing environment to produce building components and modules with modularized design and standardized interface [1], has gain more attention among researchers and practitioners. Due to reengineered construction process, prefabricated construction results in different configuration and operation in supply chain compared with traditional construction. Especially, a new decoupling point between 
manufacturing and construction process occurred [2], which means that off-site and on-site working must be coordinated. Though benefits of prefabrication method have been extensively studied, it also encounters some bottlenecks, such as high cost, lack of standard and regulations, shortage of skilled labor, lack of customer awareness, freezing design time delay [3]. Previous research indicated that poor performance of supply chain management was the main reason for low adoption of prefabricated technology [3,4]. Because on-site and off-site working sites of PCP are broken junction [5], suppliers are often not involved in prefabricated component (PC) design [6], leading to delivery delays, schedule overruns [7], on-site process disorderliness and client demands vagueness [5]. Moreover, supply chain management in construction is project-based, so it is difficult for main contractor to establish a long-term relationship with suppliers. Therefore, it is imperative to improve supplier management performance in PCP [8].

Maturity model is a useful tool to evaluate supplier management, which not only can evaluate the current maturity level but also propose a path of continuous improvement $[9,10]$. It is widely used in software engineering, information technology services, systems engineering, project management, risk management and personnel management [10]. As for SMM in construction, previous research paid more attention on traditional construction, involving implementation of supply chain management between main contractors and subcontractors [9], purchasing management maturity $[6,11]$ and supply chain relationship maturity [12]. In addition, though many researchers have devoted to study the selection and evaluation of suppliers, there is no systematic framework to assess supplier management. Naoum suggested that modern concept should be incorporated into procurement and supply chain management, such as lean construction, sustainability, building information modeling [13]. Corporation social responsibility, focusing on the value of customers and emphasizing the balance of economic, social and environmental performance, has gain more consideration in other industries. Some studies suggested that integrating corporation social responsibility into supply chain network could achieve sustainable goal of project [14]. Therefore, a research gap is found between assessing SMM and taking into consideration of corporate social and environmental responsibility.

In order to address these challenges, this study provides a glimpse into contractor-supplier bilateral relationship, exploring SMM in PCP. A maturity model is developed based on process and relationship management, particularly, corporate social responsibility is embedded initially. The purpose of this research is to identify weaknesses in supplier management and put forward strategies for continuous improvements by evaluating the maturity of supplier management. This paper is structured as follows. First, the literature about procurement management, contractor-supplier relationship and maturity model are reviewed. Then, a maturity model of supplier management is provided including assessment criteria system and maturity grid. The next section articulates the research method about data collection and statistical analysis. Subsequently, SMM of different group contractors are discussed in depth. Finally, conclusions are drawn in terms of continuous improvement for contractors in supplier management.

\section{Literature Review}

\subsection{Supply Chain and Supplier Management in PCP}

The concept of supply chain management (SCM) was initially introduced in construction industry from manufacturing industry in 1980s [15], it means management on materials flows, information flows, financial flows in project process and coordination of relationship among clients, designer, supplier and other parties to achieve cost, quality and time performance. Research on SCM focused on two domains, supply process management and supplier management [16].

Prior research paid more attention to supply chain process management in PCP. Masood used value stream mapping to explore the value chain of the prefabricated housing process and found eight common wastes in PCP value chain [4]. Stroebele identified the key factors of supply chain management by analyzing value chain of prefabricated houses [17]. In addition, lean thinking has 
been widely used in PCP supply chain management; Naim and Barlow proposed a conceptual "leagile" supply chain model which integrated lean thinking and agile production in UK customized housing supply chain to achieve technical efficiency and process responsiveness [18]. Eriksson adopted lean thinking into manufacture, logistic and construction stages, it could achieve waste reduction, production control and continuous improvement [19]. Mostafa proposed a synergistic supply chain model of prefabricated house building, including an integration of lean and agile conception with Last Planner System for coordination among stakeholders [2]. Furthermore, resource scheduling in manufacture, transportation and assembly (MtA) processes were researched extensively. Anvari adopted GA-based searching technique to solve the resource scheduling problem in the MtA process, aiming at minimizing delivery time and cost while maximizing safety [20]. Khalili proposed a mixed integer linear programming model to configure modules in order to achieve resource optimization and cost reduction [21]. Wang developed a production scheduling model based on whole PC supply chain, which integrated PC manufacturing, storing and transportation processes [22]. Similarly, IT technology and optimization algorithm were embedded in production scheduling [23], personnel allocation [24], mechanical layout [25] and material transportation management [26,27] in PCP.

In terms of supplier management, integration and collaboration between upstream and downstream participants are the main theme [16], which could improve project efficiency and quality. Hofman pointed that both supplier and contractor needed cooperation for developing, manufacturing and distributing product at multi-project level to decline cost and achieve economies of scale in PCP [28]. Meng measured the relationship between key partners in dimensions of objective, trust, collaboration, communication, problem solving, risk allocation and continuous improvement [12]. Seuring emphasized the importance of information sharing in supply chain management, which could reduce project risk and improve project performance [29]. Trust and communication are the cornerstones of achieving long-term cooperation. BIM technology break the organization boundary and make inter-organizational and intra-organizational communication possible [30]. Additionally, reasonable interest and risk sharing mechanisms can make a balance between participant interest and project overall performance [22].

\subsection{Supply Chain Management Maturity Model}

Maturity model is a descriptive instrument to assess the maturity of competency, capability and complexity [10] and a prescriptive tool to come up with a roadmap for performance improvement [31], which was originally applied to quality management. Crosby proposed a framework of quality management with five evolutionary levels, uncertainty, awakening, enlightenment, wisdom and certainty to evaluate organization status, cost of quality, problem handling and improvement action [32]. Subsequently, Capability Maturity Model was developed by software engineering institute to help developers upgrade software process, improve quality and reduce cost [33], the maturity grid of this model is divided into initial, repeatable, defined, managed and optimizing [10]. In project management domain, PMI launched OPM3 (organizational project management maturity model) in 2003 [34], which provided users with richness knowledge and self-assessment criteria to identify the current state of organization and improve delivery capabilities. Supply chain maturity is closely related to operational performance, which is a structured diagnostic tool to evaluate operational capabilities of supply network based on process formality and management practice, identify potential capability for performance improvement [14]. Several supply chain maturity models were proposed in previous studies, supply chain management business process orientation (SCM-BPO) [35], supply chain maturity model (SCM2), logistics maturity evaluator(LME) [36], supply chain capability maturity model (SCCMM) [37], supply chain process management maturity model (SCPM3) [12], these models focused on asset management, SCM skill development, strategic sourcing, maintenance and supplier relationship management.

Broft et al. evaluated supply chain maturity between main contractors and subcontractors in the Dutch construction industry, indicating that most contractors kept a low level of supply chain 
maturity [9]. Lith et al. proposed a theoretical framework for the assessment of purchasing maturity in construction and carried out a longitudinal multiple case study; the results demonstrated continuous improvement in purchasing management maturity due to IT, which enhanced the coordination and integration of construction process [6]. Meng et al. merely focused on key relationship in construction supply chain, providing an effective framework for measuring and evaluating the maturity of supply chain relationship [12].

\subsection{Research Aims and Framework}

Previous research has enriched the maturity theory in supply chain management but most supply chain maturity models focused on whole chain management from upstream and downstream, little research concerned contractor-supplier bilateral relationship management. Especially, contractor-supplier relationship should be matched with modular product architecture in PCP [28]. Besides, many supply chain maturity models developed the assessment criteria system based on process and operation management, corporate social responsibility was rarely covered. Finally, former studies adopted holistic maturity level ignoring difference of each indicator or dimension. Therefore, there is still a research gap between developing a systematic SMM model and integrating the concept of corporate social responsibility in the context of modern method of construction.

The aim of this research is to develop a systematic maturity model of supplier management that enables effective evaluation of management activities and organizational routines between contractor and supplier. Besides, empirical study is conducted, for one thing, to test and verify the availability of maturity model and assess SMM status of surveyed contractors for another. The research framework is set out in Figure 1.

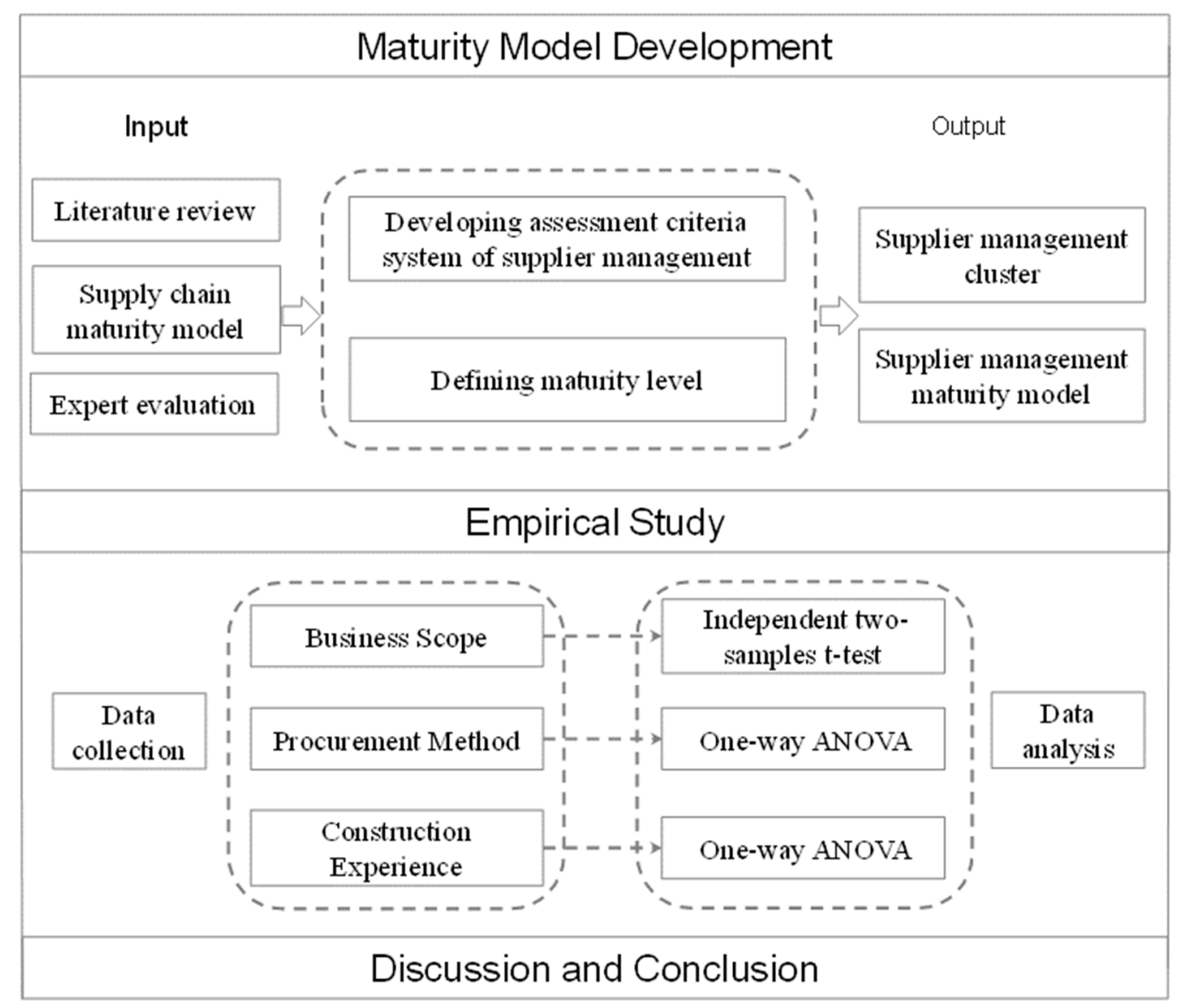

Figure 1. Research framework. 


\section{Supplier Management Maturity Model}

\subsection{Developing Assessment Criteria System of Supplier Management}

There is no consensus on the implication and measurement of supply chain management between main contractors and suppliers. This paper intends to develop an evaluation criteria system based on extensive literature review and expert interview. The searched literature mostly focused on procurement management, relationship management and sustainable supply chain. The concepts, factors and indicators in Broft, Badi et al. [9], Correia, Carvalho et al. [10], Tontini, Carvalho et al. [11], Meng, Sun et al. [12], Srai, Alinaghian et al. [14], Iii, A.L. et al. [37], Frödell, M et al. [38] were examined. It is found that previous research of supplier management was separated in operational process and supplier relationship management. This research integrated these indicators in a theoretical framework, which consists five dimensions, procurement process, operation efficiency, relationship coordination, strategic alignment, corporate social responsibility.

\subsubsection{Procurement Process}

Main contractors put substantial turnover on procurement of materials, equipment and working labors, so the management of purchasing has a big effect on overall performance of main contractor [6]. Procurement of prefabricated component plays an important role in PCP implementation. At present, the production capacity of PC supplier cannot achieve economies of scale, because high procurement cost impeded the adoption of prefabricated technology [39]. Therefore, choosing reasonable supplier is the premise to realize the economic benefit of PCP.

Procurement of PC production contains a set of procedures, from making purchasing plan, choosing optimal suppliers, to signing and executing procurement contract. Because procurement plan is project-based and method of procurement in construction is mainly based on bid and tender, contractor and supplier cannot establish a long-tern cooperation, which may increase the uncertainty of production quality and overrun cost [39]. Tontini assessed maturity levels of procurement and supply management from the dimension of materials management, purchase process, supplier evaluation process and process of procurement planning [11]. Jääskeläinen adopted a fuzzy approach to developing a procurement schedule in engineering procure construct projects, which could effectively solve inaccurate estimation of activity duration and lead times and stage budget constraints [40]. Seth et al. developed a multi-criteria decision making (MCDM) framework to evaluate the impact of competitive conditions on supplier capability in construction industry [41].

\subsubsection{Operation Efficiency}

Operation management means product and process management of suppliers from PC manufacturing, transportation to on-site scheduling. Bemelmans verified that many initiatives has been established in operational supply to improve buyer-supplier relationships [42]. PC supplier should engage in design process at an early stage in order to provide product with standard interface, reduce conflict and achieve assembly effectiveness [1]. Broft used partner involvement and process integration to depict project activities integration [9]. On-time delivery of PC and continuous order with supplier are important for supplier and main contractor. Otherwise, it could delay the whole construction process and increase the cost for logistics and storage of product [4]. For PC supplier, it may cause production line crowed of redundant and have detrimental effect on business performance. Lean and agile concept could effectively sharp the problem in manufacture, transportation and on-site scheduling, which could enhance the flexibility of the supply chain, reduce waste and achieve client requirement as possible. Eriksson assessed lean construction form the aspects of waste reduction, process focus, end customer focus continuous improvement, cooperative relationships, system perspective [19]. Particularly, information integration and communication are critical factors for supply chain operation. 


\subsubsection{Relationship Coordination}

Besides of technical problem such as activity and information integration, the critical challenges of supply chain management in PCP comes from behavior factors including attitude, relationship and communication [43]. Supply chain in construction always be blamed to fragmentation, adverse relationship, poor communication and lack of trust and commitment. As the character of modularity in $\mathrm{PCP}$, main contractor needs more leadership and collaboration at the lower ties in construction supply chain management [9], which could promote technological innovation, mitigate construction risk, ensure just-in-time delivery, reduce cost and achieve environmental performance. Especially at the $R \& D$ phase of industrialization, cooperation tends to be more relational to strengthen trust and learning among actors [29]. Bilateral communication and information sharing between buyer and suppliers are more essential than transactional activity [40]. Win-win relationship between supplier and contractor is an interact model, where contractor will provide support for supplier to reduce cost and improve quality. In order to realize the win-win goals, effective incentive mechanism must be established to ensure a reasonable allocation of profits. In addition, trust as a tacit behavior could promote knowledge sharing, improve productivity and reduce transaction cost. Information Technology is treated as a useful tool to support supply chain cooperation and improve information flow.

\subsubsection{Strategy Alignment}

The essence of supply chain management is to achieve value creation, it requires common objectives and a long-term cooperation among partners to dedicate to value increment. Lith et al. suggested to establish strategic relationships and integrate suppliers into the value creation process in supply chain management [6]. Strategic partnering as an effective way to deal with the problems of work fragmentation, lack of integration and adversarial relationship [9]. However, partnering participants cannot obtain long-term cooperation and achieve performance in construction, due to the project-based supply chain. Furthermore, most partner are driven by profit, so it is hardly for them to spare any effort on extra aspects, such as technical innovation and waste reduction.

\subsubsection{Corporation Social Responsibility}

Corporate social responsibility (CSR) refers to the ethical principle that an organization should be responsible for how its behavior might affect society and the environment, which means companies are focusing on the impacts of their operations not only on profits but the society and environment aspects at large [44]. Recent years, corporation social responsibility is becoming increasingly important. It covers topics, such as corruption, sustainable development community engagement as well as occupational health and safety in construction industry [45]. Loosemore explored the relationship between CSR and organizational performance in the construction industry; the CSR strategy included workforce activities [45], supply chain activities, community engagement activities and environmental activities. However, this research measure supplier's CSR from the dimension of social aspect, such as wages and welfare, occupational health and safety and training of workers and environmental aspect, such as waste of materials, green design and technique, construction waste, energy saving and emission reduction and implementation of environmental standard.

To improve the reliability and validity of the survey, we referred to measurement items from previous validated study as much as possible. Moreover, a workshop was launched including 7 academic researchers, 2 construction industry experts, 3 engineers and 2 project managers, all of them had more than five years' research or practical experience in PCP supply chain management. Through three rounds meeting, an agreement on supplier management framework was reached which included evaluation criteria system and maturity level. Finally, three indicators, supplier involvement, risk allocation and motivation were deleted due to weak relationship to supplier management and several indicators were rephrased. The evaluation criteria system of SMM was established that was shown in Table 1. 
Table 1. Evaluation criteria system of supplier management maturity.

\begin{tabular}{|c|c|c|c|c|}
\hline Dimension & Code & Indicator & Definition & Sources \\
\hline \multirow{5}{*}{$\begin{array}{l}\text { Procurement } \\
\text { process (F1) }\end{array}$} & F11 & Purchasing procedure & $\begin{array}{l}\text { The specific process of procurement task, whether there } \\
\text { are relevant documents and procurement personnel }\end{array}$ & {$[9,11,12,40]$} \\
\hline & F12 & Procurement plan & $\begin{array}{l}\text { Forecasting the demand of building materials, buying } \\
\text { and restocking planning and buying lead-time }\end{array}$ & {$[6,46]$} \\
\hline & F13 & Supplier selection criteria & Qualification and regulation of supplier selection & {$[11,12,41]$} \\
\hline & F14 & Quotation and budget & $\begin{array}{l}\text { Selection and control of supplier's bidding quotation, } \\
\text { whether to establish budget control system }\end{array}$ & {$[11,13]$} \\
\hline & F15 & $\begin{array}{l}\text { Procurement contract } \\
\text { management }\end{array}$ & $\begin{array}{l}\text { Manage obligation and the right of both parties during } \\
\text { the contract execution, establish principles of benefit } \\
\text { distribution and risk sharing }\end{array}$ & {$[40]$} \\
\hline \multirow{6}{*}{$\begin{array}{l}\text { Operation } \\
\text { efficiency (F2) }\end{array}$} & F21 & Delivery time of PC & $\begin{array}{l}\text { Delivery of PC product from off-site to construction } \\
\text { site in a timely manner }\end{array}$ & {$[9,19,20,23]$} \\
\hline & F22 & Inventory management of PC & $\begin{array}{l}\text { Organization of PC area, preservation of PC quality, } \\
\text { control inventory cost }\end{array}$ & [47] \\
\hline & $\mathrm{F} 23$ & Site layout of PC & $\begin{array}{l}\text { The placement sequence and location of PC production } \\
\text { to facilitate assembly }\end{array}$ & [5] \\
\hline & $\mathrm{F} 24$ & $\begin{array}{l}\text { Production change and } \\
\text { responsibility assignment }\end{array}$ & $\begin{array}{l}\text { Change of supplier contract price and responsibility } \\
\text { due to change of product type and dimension }\end{array}$ & {$[5,12]$} \\
\hline & $\mathrm{F} 25$ & $\begin{array}{l}\text { Information sharing and } \\
\text { communication }\end{array}$ & $\begin{array}{l}\text { Information exchange between participants, sharing } \\
\text { learning and innovation }\end{array}$ & {$[9,19]$} \\
\hline & F26 & $\begin{array}{l}\text { Application of advanced } \\
\text { technology }\end{array}$ & $\begin{array}{l}\text { Advanced technology, such as BIM, RFID, applied in } \\
\text { PC design, manufacturing and assemble }\end{array}$ & [9] \\
\hline \multirow{4}{*}{$\begin{array}{l}\text { Relationship } \\
\text { coordination (F3) }\end{array}$} & $\mathrm{F} 31$ & Partnership relationship & $\begin{array}{l}\text { Establish a long-term reliable relationship based on } \\
\text { the contract }\end{array}$ & {$[38,42]$} \\
\hline & F32 & Trust & $\begin{array}{l}\text { Confidence in others' credit, qualification, financial and } \\
\text { operation ability, monitoring others' work }\end{array}$ & {$[6]$} \\
\hline & F33 & $\begin{array}{l}\text { Supplier coordination and } \\
\text { leadership }\end{array}$ & $\begin{array}{l}\text { Parties work collaboratively and how general } \\
\text { contractor play a leading role in achieving cooperation }\end{array}$ & {$[14,29]$} \\
\hline & F34 & Continuous improvement & $\begin{array}{l}\text { Feedback of performance to achieve mutual } \\
\text { advantages and values constantly }\end{array}$ & [12] \\
\hline \multirow{4}{*}{$\begin{array}{l}\text { Strategy } \\
\text { alignment (F4) }\end{array}$} & F41 & Objective alignment & $\begin{array}{l}\text { Share common goals, alignment with } \\
\text { participants strategy }\end{array}$ & [12] \\
\hline & $\mathrm{F} 42$ & Long-term cooperation & $\begin{array}{l}\text { Maintain close cooperation on multiple projects, } \\
\text { achieve inter-organizational collaboration in } \\
\text { supply chain }\end{array}$ & {$[19,42]$} \\
\hline & F43 & $\begin{array}{l}\text { Joint effort in technology } \\
\text { innovation }\end{array}$ & $\begin{array}{l}\text { A collaboration between contractors and suppliers to } \\
\text { design and manufacture building product, achieve } \\
\text { technical innovation. }\end{array}$ & {$[47,48]$} \\
\hline & F44 & Value chain integration & $\begin{array}{l}\text { Realize integration of business process and information } \\
\text { system among participants, maximize the value } \\
\text { creation of suppliers }\end{array}$ & {$[6,15]$} \\
\hline \multirow{7}{*}{$\begin{array}{l}\text { Corporate social } \\
\text { responsibility (F5) }\end{array}$} & F51 & $\begin{array}{l}\text { Fair wages and welfare of } \\
\text { workers }\end{array}$ & $\begin{array}{l}\text { Company can provide workers with decent wages and } \\
\text { sound welfare }\end{array}$ & [49] \\
\hline & F52 & $\begin{array}{l}\text { Occupational health and safety } \\
\text { of workers }\end{array}$ & $\begin{array}{l}\text { Company can execute sound regulation and take } \\
\text { measures to ensure worker's health and safety }\end{array}$ & {$[45,50]$} \\
\hline & F53 & $\begin{array}{l}\text { Training and career } \\
\text { development of workers }\end{array}$ & $\begin{array}{l}\text { Company can provide workers with career training } \\
\text { opportunity constantly and highlight on } \\
\text { workers development }\end{array}$ & {$[49,50]$} \\
\hline & F54 & $\begin{array}{l}\text { Fair competition and } \\
\text { corruption prevention }\end{array}$ & $\begin{array}{l}\text { Fair purchase procedure, non-speculative behavior and } \\
\text { corruption prevention to ensure a good } \\
\text { corporate image }\end{array}$ & {$[45]$} \\
\hline & F55 & $\begin{array}{l}\text { Implementation of } \\
\text { environment regulation and } \\
\text { standard }\end{array}$ & $\begin{array}{l}\text { Participants can implement the environmental } \\
\text { standards in the process of design, manufacture and } \\
\text { construction }\end{array}$ & [39] \\
\hline & F56 & Energy and emission reduction & $\begin{array}{l}\text { Participants can take measures to reduce energy } \\
\text { consumption, dust, noise and water }\end{array}$ & {$[14,51]$} \\
\hline & F57 & $\begin{array}{l}\text { Green design and cleaner } \\
\text { technology }\end{array}$ & $\begin{array}{l}\text { Collaboration between contractors and suppliers to } \\
\text { develop green technology applying in product design, } \\
\text { manufacturing and construction }\end{array}$ & {$[51]$} \\
\hline
\end{tabular}




\subsection{Defining Maturity Level of Supplier Management}

The maturity level defines the evolutionary characteristics of key business processes and relationship between supply partners [12]. There are four types of maturity model, structured model, maturity grid, Likert-like questionnaires and hybrid models. All indicators share the same maturity level in structured models, Likert-like questionnaires use a set of questions with a scale to evaluate the maturity level. Maturity grid develops a number of maturity levels according to the different dimensions. Based on Correia's analysis of a large amount of literature, the number of maturity levels range between three and six, while five is the most common [11]. This research adopts maturity grids, because the evaluation criteria system involves different aspects, a common maturity level cannot represent each indicator's continuous improvement.

Previous research designed the maturity level based on different principles. Supply chain maturity model, proposed by the organization of The Performance Measurement Group (PMG), designed the maturity level from functional focus, internal integration, external integration and cross-enterprise collaboration which considered the relationship between different stages of enterprise operation ability and supply chain performance [34]. Kevin McCormak developed the business process maturity of supply chains including Ad Hoc, defined, linked, integrated and extended [37]. IBM defined the continuous improvement supply chain maturity model from static supply chain, functional excellence, horizontal integration, external collaboration and on demand supply chain. This paper developed the maturity model according to the following principles: (1) achieve from decentralized business process to integrated process management; (2) achieve from intra-organizational management to inter-organizational management; (3) achieve from short-term cooperation to long-term strategic cooperation; (4) achieve from single index qualitative assessment to multi-index quantitative assessment; (5) achieve from static monitoring to dynamic continuous improvement. The general definition and description of maturity level was shown in Table 2 and the final maturity model of supplier management was represented in Appendix A.

Table 2. Definition of supplier management maturity level.

\begin{tabular}{cll}
\hline Level & \multicolumn{1}{c}{ Supply Process } & \multicolumn{1}{c}{ Organizational Relationship } \\
\hline 1 & $\begin{array}{l}\text { Unstructured and ill-defined supply chain } \\
\text { processes, undefined procurement procedure, } \\
\text { disordered operation management. }\end{array}$ & $\begin{array}{l}\text { One-time contractual relationship just based on } \\
\text { purchasing activities, no partnership has } \\
\text { been established. }\end{array}$ \\
\hline 2 & $\begin{array}{l}\text { Supply processes are being developed but } \\
\text { defined processes are separate from one another, } \\
\text { on-site and off-site operation management are } \\
\text { disconnected. }\end{array}$ & $\begin{array}{l}\text { Intra-organizational processes optimization to } \\
\text { meet its goals, begin to establish communication } \\
\text { in certain supply activity. }\end{array}$ \\
\hline 3 & $\begin{array}{l}\text { Measurement system are applied to manage } \\
\text { process performance, including supplier } \\
\text { evaluation and supply activity efficiency. }\end{array}$ & $\begin{array}{l}\text { Establishing short-term cooperation with } \\
\text { suppliers in certain project, frequent } \\
\text { communication in supply activities. }\end{array}$ \\
\hline 4 & $\begin{array}{l}\text { Integrated processes with suppliers, off-site and } \\
\text { on-site activities are synergistic, quantitative } \\
\text { supplier evaluation system, long-term } \\
\text { procurement plan. }\end{array}$ & $\begin{array}{l}\text { Establish formal partnership relationship, } \\
\text { decentralize some technical innovation activities } \\
\text { to suppliers, provide support with multi resource } \\
\text { in inter-organization. }\end{array}$ \\
\hline 5 & $\begin{array}{l}\text { Continuous improvement to its processes, adapt } \\
\text { to meet owner's needs dynamically, enable } \\
\text { responsiveness to environmental changes }\end{array}$ & $\begin{array}{l}\text { Strategic coordination with suppliers in business, } \\
\text { long-term cooperation in multiple project, full } \\
\text { inter-organizational communication integration. }\end{array}$ \\
\hline
\end{tabular}

\section{Research Method}

\subsection{Data Collection}

This research was carried out in the area of Yangtze River delta which was one of the biggest and most leading areas in developing modern method of construction in China. With support of government, 102 PCP demonstration sites, 40 demonstration projects, 5 PCP training bases have been established, thus, a number of preeminent contractors emerged. A directory including 65 PCP 
contractors was issued in September 2017 by the Chinese Ministry of Construction. All contractors are large companies (even group companies), which have involved or are setting foot in modern method of construction. The survey was conducted on the base of 65 contractors. After contacting them by telephone, e-mails and social media, 12 contractors refused and 5 were out of connection. Then the questionnaire was distributed to the rest contractors through multiple ways, including field research, web-based survey and E-mail. In order to ensure credibility and representativeness of the data, respondents were suggested to those who had been engaged in modular building procurement and supplier management, including senior manager, purchasing manager, main engineer and administrative manager of contractors. Finally, 34 valid questionnaires were received, representing $52.3 \%$ of the surveyed contractors.

The questionnaire consists of two parts, one is the basic information, involving company's name, qualification, business scope, procurement method, construction experience and respondent information. Part two is the assessment of maturity level of supplier management in PCP, the questionnaire includes 30 questions totally, covering six dimensions and each question was made up of five maturity options from low to high scaled by 1 to 5 . Before distributing to the surveyed contractors, a pilot survey was conducted towards three PCP contractors.

Table 3 demonstrated the descriptive analysis of 34 contractors studied in terms of business scope, procurement method, number of contracted PCP project. Of the surveyed contractors, most $(79 \%)$ engaged in diversified business, $44 \%$ adopted the procurement method of Engineering Procurement Construction (EPC), Engineering Manufacturing Procurement Construction (EMPC) and Design Bid Build (DBB) occupied $26 \%$ and $29 \%$ respectively. As for construction experience, almost half of the contractors have undertaken fewer than $5 \mathrm{PCP}$ projects.

Table 3. Descriptive analysis.

\begin{tabular}{ccc}
\hline Items & Frequency & Percent \\
\hline Business scope & & \\
\hline $\begin{array}{c}\text { Single business } \\
\text { Diversified business }\end{array}$ & 7 & 20.59 \\
\hline Procurement method & & \\
\hline EPC & 15 & 49.41 \\
EMPC & 9 & 26.47 \\
DB & 10 & 29.41 \\
\hline Number of contracted PCP & & \\
\hline$<5$ & 14 & 41.18 \\
$5-10$ & 10 & 29.41 \\
$>10$ & 10 & 29.41 \\
\hline
\end{tabular}

Reliability analysis of questionnaire was tested through SPSS. The coefficient of Cronbach's alpha plays an important role in reliability test, in principle, if the value of Cronbach's alpha $>0.7$, the design of questionnaire is credible. In this research, the coefficient of Cronbach's alpha in each dimension is shown in Table 4. Though Cronbach's alpha of all the dimensions are more than 0.7 , if item "site layout of prefabricated component" is deleted, the Cronbach's alpha will increase to 0.765 . If item "energy and emission reduction" is deleted, the Cronbach's alpha will increase to 0.825 . In reality, the content of "site layout of prefabricated component" is embedded in "inventory management of PC," "energy and emission reduction" is implemented and supervised by the manufacture rather than contractor. Finally, taking these reasons into consideration, the indicator system was updated, item "site layout of prefabricated component" and item "energy and emission reduction" were deleted. 
Table 4. Reliability statistics.

\begin{tabular}{ccc}
\hline Dimension & Number of Items & Cronbach's Alpha \\
\hline Purchase process & 5 & 0.849 \\
Operation efficiency & 5 & 0.765 \\
Relationship coordination & 4 & 0.826 \\
Strategic alignment & 4 & 0.813 \\
Corporate social responsibility & 6 & 0.825 \\
\hline
\end{tabular}

\subsection{Data Analysis}

Mean value comparison is used to test the difference of mean value about different samples to explain the statistical significance and population difference. SPSS 20.0 software was adopted to analysis the data. Independent two-samples $t$-test and one-way analysis of variance (ANOVA) were employed in this research.

Independent two-samples $t$-test is used to determine if two independent sample data are significantly different from each other [52]. A two-sample location test of the null hypothesis such that the means of two populations are equal. This test method was applied under the following conditions: (1) the sample data come from the population of normal distribution; (2) the two distributions have the same variance, Levene's test was used for equality of variances; (3) the size of two samples should be equal. The $t$ statistic to test whether the means are different can be calculated as follows:

$$
t=\frac{\overline{X_{1}}-\overline{X_{2}}}{s_{p} \sqrt{\frac{2}{n}}}
$$

where

$$
s_{p}=\sqrt{\frac{s^{2} X_{1}+s^{2} X_{2}}{2}}
$$

$s_{p}$ is the pooled standard deviation for $n=n_{1}=n_{2}, s_{X_{1}}^{2}$ and $s_{X_{2}}^{2}$ are the unbiased estimator of the variances of the two samples.

However, in terms of unequal sample sizes and unequal variances, Welch-Satterthwaite equation could be adopted where the corrected $t$-test or non-parametric test are used to compare the means between two samples [53].

One-way ANOVA is suitable for comparing means more than two samples. The null hypothesis is that samples in all groups are drawn from populations with the same mean values [54]. One-way ANOVA is performed under the following assumptions: (1) the measurement variable residuals are approximately normally distributed; (2) the variances of populations are equal; (3) responses for each group are independent and identically distributed normal random variables. Calculations of the means and the variance are performed as part of the hypothesis test. The commonly used normal linear models for a completely randomized experiment are [55]:

$$
y_{i, j}=\mu+\tau_{j}+\varepsilon_{i, j}
$$

$\mu$ is the grand mean of the observations;

$\tau_{j}$ is the treatment effect which is a deviation from the grand mean, $\sum \tau_{j}=0, \mu_{j}=\mu+\tau_{j}$

$\varepsilon \sim N\left(0, \sigma^{2}\right), \varepsilon_{i, j}$ are normally distributed zero-mean random errors.

Bonferroni is used to test the mean difference between pairwise groups in the Post Hoc test. The advantage of this method is that the number of samples in each group can be different and the result is better in the case of limited comparison. 


\section{Results}

\subsection{Overall Maturity Level of Supplier Management}

Table 5 details the mean value of SMM in each dimension. The highest score comes to "operation efficiency" (F2, 3.41), "purchase process" (F1, 3.37) and "corporate social responsibility" (F5, 3.23) rank in second and third level respectively, the maturity score of "strategy alignment" (F4) is just 2.99 which stands in the lowest level.

Table 5. Descriptive Statistics.

\begin{tabular}{ccccc}
\hline Dimensions & Min & Max & Mean & Std. Dev \\
\hline Purchase process & 2.00 & 4.60 & 3.37 & 0.648 \\
Operation efficiency & 2.40 & 4.20 & 3.41 & 0.490 \\
Relationship coordination & 2.00 & 4.25 & 3.11 & 0.607 \\
Strategic alignment & 1.75 & 4.00 & 2.99 & 0.584 \\
Corporate social responsibility & 2.33 & 4.00 & 3.23 & 0.338 \\
\hline
\end{tabular}

The maturity level of each sub-indicator is shown in Figure 2; "occupational health and safety of workers" (F52), "supplier selection criteria" (F13) and "delivery time of PC" (F21) rank in the top three; particularly, F52 stands at the fourth maturity level. However, the results indicate that "implementation of environment regulation and standard" (F55), "green design and cleaner technology" (F57) and "flexibility to client demand" (F44) remain in bottom level, all of them stay in the second level maturity.

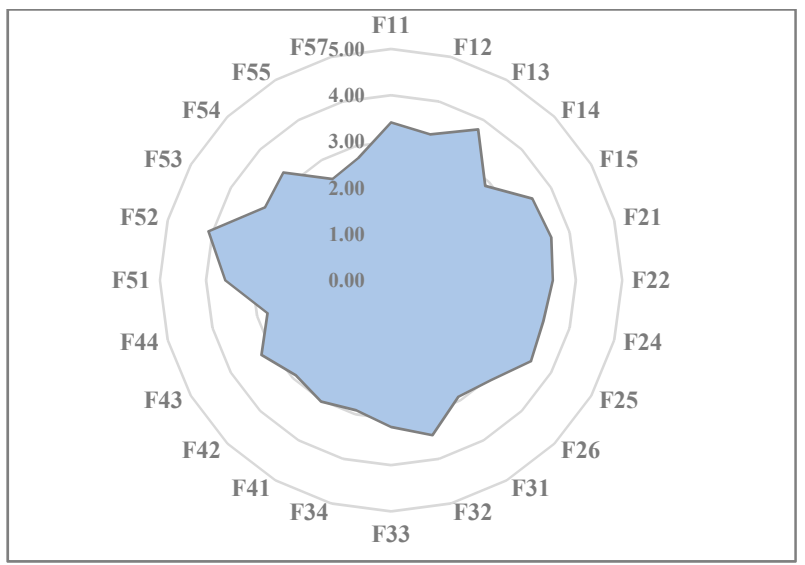

Figure 2. Maturity level of each items.

\subsection{Maturity Analysis of Different Group of Contractors}

In order to get a deeper understanding of SMM, surveyed contractors are divided into different groups according to the business scope, procurement method and construction experience. Independent two-sample $t$-test and one-way ANOVA method are adopted to analyze the difference of maturity mean value among different groups.

\subsubsection{Independent Two-Samples t-Test for Contractor's Business Scope}

There are two types of contractor's business scope, single business and diversified business. Single business contractor narrows its business in some specific area. In this research, most contractors focus on design, manufacture and construction of steel structure buildings, covering steel structure house, public building and infrastructure. By contrast, diversified contractor involves a wide portfolio of business, such as real estate development, equipment installation, building decoration municipal public utilities and so on. Nowadays, they expand their traditional business scope to modern method 
of construction, many contractors start involving in PCP, including prefabricated concrete housing and modular production. Independent two-samples $t$-test is conducted to explore the difference of mean value between two groups, as shown in Table 6.

Table 6. Group statistic and Independent Samples Test.

\begin{tabular}{|c|c|c|c|c|c|c|c|}
\hline \multirow[b]{2}{*}{ Dimensions } & \multirow[b]{2}{*}{ Business Scope } & \multirow[b]{2}{*}{$\mathbf{N}$} & \multirow[b]{2}{*}{ Mean } & \multirow{2}{*}{$\begin{array}{c}\text { Std. } \\
\text { Deviation }\end{array}$} & \multicolumn{3}{|c|}{$t$-Test for Equality of Means } \\
\hline & & & & & $\mathbf{T}$ & $\begin{array}{c}\text { Sig. } \\
\text { (2-Tailed) }\end{array}$ & $\begin{array}{c}\text { Mean } \\
\text { Difference }\end{array}$ \\
\hline \multirow{2}{*}{$\begin{array}{c}\text { Procurement } \\
\text { process }\end{array}$} & Single & 7 & 3.97 & 0.315 & \multirow{2}{*}{3.090} & \multirow{2}{*}{0.004} & \multirow{2}{*}{0.757} \\
\hline & Diversified & 27 & 3.21 & 0.622 & & & \\
\hline \multirow{2}{*}{$\begin{array}{l}\text { Operation } \\
\text { efficiency }\end{array}$} & Single & 7 & 3.80 & 0.327 & \multirow{2}{*}{3.175} & \multirow{2}{*}{0.007} & \multirow{2}{*}{0.489} \\
\hline & Diversified & 27 & 3.31 & 0.478 & & & \\
\hline \multirow{2}{*}{$\begin{array}{l}\text { Relationship } \\
\text { coordination }\end{array}$} & Single & 7 & 3.79 & 0.304 & \multirow{2}{*}{5.419} & \multirow{2}{*}{0.000} & \multirow{2}{*}{0.841} \\
\hline & Diversified & 27 & 2.94 & 0.543 & & & \\
\hline \multirow{2}{*}{$\begin{array}{l}\text { Strategy } \\
\text { alignment }\end{array}$} & Single & 7 & 3.50 & 0.289 & \multirow[b]{2}{*}{2.896} & \multirow[b]{2}{*}{0.007} & \multirow[b]{2}{*}{0.648} \\
\hline & Diversified & 27 & 2.85 & 0.569 & & & \\
\hline \multirow{2}{*}{$\begin{array}{l}\text { Corporate social } \\
\text { responsibility }\end{array}$} & Single & 7 & 3.33 & 0.096 & \multirow{2}{*}{0.901} & \multirow{2}{*}{0.375} & \multirow{2}{*}{0.130} \\
\hline & Diversified & 27 & 3.20 & 0.374 & & & \\
\hline
\end{tabular}

It is noticed that the variances of two groups are unequal through Levene's test, thus the corrected $t$-test is used. Besides "corporate social responsibility" (F5, 0.375), other dimensions are difference significantly at $p<0.05$ in the two-sided test of equality for mean values between single business group and diversified business group. In general, SMM of single business contractor is significantly higher than diversified contractor, especially in "relationship coordination" (F3) and "strategic alignment" (F4). As for diversified business contractor, they lay more stress on "operation efficiency" (F2) and "procurement process" (F1).

The maturity score of each item is shown in Figure 3. There is a big gap in maturity level of "objective alignment" (F41), "supplier selection criteria" (F13) and "partnership relationship" (F31), The maturity score gap among item "implementation of environment regulation and standard" (F55), "occupational health and safety of workers" (F52) and "joint effort in technology innovation" (F43) are shrink. However, "fair wages and welfare of workers" (F51) of single business group is lower than that of diversified business group.

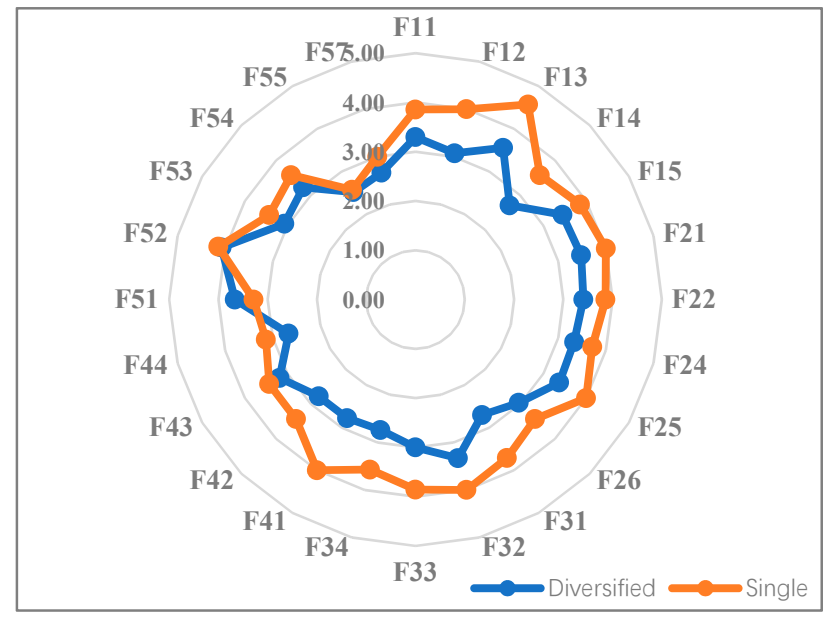

Figure 3. Maturity level of each items among business scope groups.

\subsubsection{One-Way ANOVA Test for Procurement Method}

Surveyed contractors are involved in three procurement methods, EPC, EMPC and DBB. EPC means that the main contractor charges the whole process for design, procurement and construction 
of the PCP project under the commission of client. EMPC embeds the prefabricated component manufacturing on the basis of EPC. Generally, these contractors own affiliated PC factories to provide product for self-build project. DBB contractors are mainly responsible for assembly onsite and sometimes charge procurement of components.

As shown in Table 7, EPC contractors have high maturity level of "operation efficiency" (F2, 3.56) and "procurement process" (F1, 3.44) but relatively poor in "relationship coordination" (F3, 3.10) and "strategic alignment" (F4, 3.05), all the dimensions stand in third maturity level. Getting high maturity score on "operation efficiency" (F2, 3.80) and "procurement process" (F1, 4.00), EMPC contractors also attach more importance on "relationship coordination" (F3, 3.83) and "strategic alignment" (F4, 3.61), all dimensions stay in third maturity level, "procurement process" even stands in fourth level. By contrast, DBB contractor has high maturity level in "corporate social responsibility" (F5, 3.08), other dimensions stay in second maturity level. It is indicated that the average maturity of supplier management for EMPC contractor is always higher than that of EPC and DBB.

Table 7. Multiple Comparisons of groups with different procurement methods.

\begin{tabular}{|c|c|c|c|c|c|c|c|c|}
\hline \multirow[b]{2}{*}{ Dimension } & \multirow{2}{*}{$\begin{array}{l}\text { Procurement } \\
\text { Method }\end{array}$} & \multirow[b]{2}{*}{ Mean } & \multirow{2}{*}{$\begin{array}{c}\text { Std. } \\
\text { Deviation }\end{array}$} & \multicolumn{3}{|c|}{ Post Hoc } & \multicolumn{2}{|c|}{ ANOVA } \\
\hline & & & & $\begin{array}{c}\text { Dependent } \\
\text { Variable }\end{array}$ & $\begin{array}{c}\text { Mean } \\
\text { Difference }\end{array}$ & Sig. & Items & Sig. \\
\hline \multirow{6}{*}{$\begin{array}{l}\text { Procurement } \\
\text { process }\end{array}$} & \multirow[b]{2}{*}{ EPC } & \multirow[b]{2}{*}{3.44} & \multirow[b]{2}{*}{0.525} & EMPC & -0.560 * & 0.013 & \multirow{3}{*}{$\begin{array}{l}\text { Between } \\
\text { Groups }\end{array}$} & \multirow{6}{*}{0.000} \\
\hline & & & & DBB & 0.740 * & 0.001 & & \\
\hline & \multirow{2}{*}{ EMPC } & \multirow{2}{*}{4.00} & \multirow{2}{*}{0.200} & EPC & $0.560 *$ & 0.013 & & \\
\hline & & & & DBB & 1.300 * & 0.000 & \multirow{3}{*}{$\begin{array}{l}\text { Within } \\
\text { Groups }\end{array}$} & \\
\hline & \multirow{2}{*}{ DBB } & \multirow{2}{*}{2.70} & \multirow{2}{*}{0.414} & EPC & $-0.740 *$ & 0.001 & & \\
\hline & & & & DBB & $-1.300 *$ & 0.000 & & \\
\hline \multirow{6}{*}{$\begin{array}{l}\text { Operation } \\
\text { efficiency }\end{array}$} & \multirow[b]{2}{*}{ EPC } & \multirow[b]{2}{*}{3.56} & \multirow[b]{2}{*}{0.322} & EMPC & -0.240 & 0.225 & \multirow{3}{*}{$\begin{array}{l}\text { Between } \\
\text { Groups }\end{array}$} & \multirow{6}{*}{0.000} \\
\hline & & & & DBB & 0.720 * & 0.000 & & \\
\hline & \multirow{2}{*}{ EMPC } & \multirow{2}{*}{3.80} & \multirow{2}{*}{0.265} & EPC & 0.240 & 0.225 & & \\
\hline & & & & DBB & 0.960 * & 0.000 & \multirow{3}{*}{$\begin{array}{l}\text { Within } \\
\text { Groups }\end{array}$} & \\
\hline & & & & EPC & -0.720 * & 0.000 & & \\
\hline & DBB & 2.84 & 0.324 & DBB & $-0.960 *$ & 0.000 & & \\
\hline & & & & EMPC & -0.733 * & 0.000 & & \\
\hline & EPC & 3.10 & 0.399 & DBB & $0.600 *$ & 0.001 & Between & 0.000 \\
\hline Relationship & FMPC & 383 & 0250 & EPC & $0.733 *$ & 0.000 & Groups & \\
\hline coordination & EMPC & 3.83 & 0.250 & DBB & 1.333 * & 0.000 & & \\
\hline & $\mathrm{DBR}$ & & & EPC & $-0.600 *$ & 0.001 & Within & \\
\hline & DBB & 2.50 & 0.333 & DBB & $-1.333 *$ & 0.000 & Groups & \\
\hline & & & & EMPC & -0.561 * & 0.001 & & \\
\hline & ЕРC & 3.05 & 0.368 & DBB & $0.725 *$ & 0.000 & $\begin{array}{l}\text { Between } \\
\text { Grouns }\end{array}$ & 0.000 \\
\hline Strategy & & & & EPC & 0.561 * & 0.001 & & \\
\hline alignment & EMPC & 3.61 & 0.253 & DBB & $1.286^{*}$ & 0.000 & & \\
\hline & DRB & & & EPC & $-0.725^{*}$ & 0.000 & $\begin{array}{l}\text { Within } \\
\text { Grouns }\end{array}$ & \\
\hline & DBB & 2.33 & 0.313 & DBB & $-1.286^{*}$ & 0.000 & & \\
\hline & & & & EMPC & -0.067 & 1.000 & & \\
\hline & EPC & 3.27 & 0.392 & DBB & 0.183 & 0.564 & Between & 0.241 \\
\hline $\begin{array}{l}\text { Corporate } \\
\text { social }\end{array}$ & FMPC & 333 & 0.220 & EPC & 0.067 & 1.000 & & \\
\hline responsibility & & 3.33 & 0.220 & DBB & 0.250 & 0.339 & Within & \\
\hline & DBB & 3.08 & 0.317 & EPC & -0.183 & 0.564 & Groups & \\
\hline
\end{tabular}

* The mean difference is significant at the 0.05 level.

In addition, by performing analysis of variance (ANOVA), besides "corporate social responsibility" (F5), there is a significant difference $(p<0.05)$ in other dimensions between groups. There is a significant different among all groups in terms of "procurement process" (F1), "relationship coordination" (F3) and "strategic alignment" (F4) by multiple comparisons. In detail, EMPC contractors always stay in a leading maturity level followed by EPC contractors, DBB contractors are in the bottom stage. As for "operation efficiency" (F2, $p=0.225)$, there is an overlap between EPC contractor and EMPC contractor but both of them have a higher maturity level than DBB contractor significantly. It is worth noticing that we cannot distinguish the maturity of "corporate social responsibility" (F5) among all groups. 


\subsubsection{One-Way ANOVA Test for PCP Construction Experience}

As for construction experience in PCP, a quantitative indicator-the number of contracted PCP project, is proposed to measure construction experience. Group 1 has contracted less than 5 PCPs; most dimensions of supplier management remain at the second maturity level. They pay more attention to "operation efficiency" (F2, 2.99) and "procurement process" (F1, 2.73) rather than "relationship coordination" (F3, 2.54) and "strategic alignment" (F4, 2.55). "Corporate social responsibility" (F5, 3.08) comes to the first and stands in the third maturity level. Group 2 has contracted PCPs from 5 to 10, all the dimensions lie in the third maturity level, "operation efficiency" (F2, 3.52) and "procurement process" (F1,3.58) have higher maturity scores than "relationship coordination" $(\mathrm{F} 3,3.28)$ and "strategic alignment" (F4, 3.05). "Corporate social responsibility" (F5, 3.30) stand in the middle stage. Having contracted PCPs more than 10, Group 3 has rich experience in PCP by comparison. All the dimensions have higher maturity levels, especially, "procurement process" (F1, 4.06) situates in the fourth level. It can be seen from multiple comparisons (Table 8$)$, there is a significant difference $(p<0.05)$ for all dimensions maturity among different groups except "corporate social responsibility" (F5).

Table 8. Multiple Comparisons of groups with different construction experience.

\begin{tabular}{|c|c|c|c|c|c|c|c|c|}
\hline \multirow[b]{2}{*}{ Dimension } & \multirow{2}{*}{$\begin{array}{l}\text { Construction } \\
\text { Experience }\end{array}$} & \multirow[b]{2}{*}{ Mean } & \multirow{2}{*}{$\begin{array}{c}\text { Std. } \\
\text { Deviation }\end{array}$} & \multicolumn{3}{|c|}{ Post Hoc } & \multicolumn{2}{|c|}{ ANOVA } \\
\hline & & & & $\begin{array}{c}\text { Dependent } \\
\text { Variable }\end{array}$ & $\begin{array}{c}\text { Mean } \\
\text { Difference }\end{array}$ & Sig. & Items & Sig. \\
\hline \multirow{6}{*}{$\begin{array}{l}\text { Procurement } \\
\text { process }\end{array}$} & \multirow{2}{*}{ Poor } & \multirow{2}{*}{2.73} & \multirow{2}{*}{0.320} & Middle & $-0.851 *$ & 0.000 & \multirow{3}{*}{$\begin{array}{l}\text { Between } \\
\text { Groups }\end{array}$} & \multirow{6}{*}{0.000} \\
\hline & & & & High & $-1.331 *$ & 0.000 & & \\
\hline & \multirow{2}{*}{ Middle } & \multirow{2}{*}{3.58} & \multirow{2}{*}{0.305} & Poor & $0.851 *$ & 0.000 & & \\
\hline & & & & High & -0.480 * & 0.004 & \multirow{3}{*}{$\begin{array}{l}\text { Within } \\
\text { Groups }\end{array}$} & \\
\hline & \multirow{2}{*}{ High } & \multirow{2}{*}{4.06} & \multirow{2}{*}{0.284} & Poor & 1.331 * & 0.000 & & \\
\hline & & & & Middle & $0.480 *$ & 0.004 & & \\
\hline \multirow{6}{*}{$\begin{array}{l}\text { Operation } \\
\text { efficiency }\end{array}$} & \multirow{2}{*}{ Poor } & \multirow{2}{*}{2.99} & \multirow{2}{*}{0.380} & Middle & -0.534 * & 0.001 & \multirow{3}{*}{$\begin{array}{l}\text { Between } \\
\text { Groups }\end{array}$} & \multirow{6}{*}{0.000} \\
\hline & & & & High & $-0.914^{*}$ & 0.000 & & \\
\hline & \multirow{2}{*}{ Middle } & \multirow{2}{*}{3.52} & \multirow{2}{*}{0.215} & Poor & 0.534 * & 0.001 & & \\
\hline & & & & High & $-0.380 *$ & 0.027 & \multirow{3}{*}{$\begin{array}{l}\text { Within } \\
\text { Groups }\end{array}$} & \\
\hline & High & 390 & 0254 & Poor & 0.914 * & 0.000 & & \\
\hline & Hign & 3.90 & 0.254 & Middle & $0.380 *$ & 0.027 & & \\
\hline & & & & Middle & -0.739 * & 0.000 & & \\
\hline & Poor & 2.54 & 0.323 & High & $-1.239 *$ & 0.000 & Between & 0.000 \\
\hline Relationship & & & & Poor & 0.739 * & 0.000 & Groups & \\
\hline coordination & Middle & 3.28 & 0.322 & High & $-0.500 *$ & 0.003 & Within & \\
\hline & & & & Poor & $1.239 *$ & 0.000 & Within & \\
\hline & High & 3.78 & 0.249 & Middle & 0.500 * & 0.003 & Groups & \\
\hline & & & & Middle & $-0.496^{*}$ & 0.026 & & \\
\hline & Poor & 2.55 & 0.511 & High & $-0.971 *$ & 0.000 & Between & 0.000 \\
\hline Strategy & & 305 & 0453 & Poor & $0.496^{*}$ & 0.026 & & \\
\hline alignment & Middle & 3.05 & 0.453 & High & -0.475 & 0.056 & & \\
\hline & High & 3.52 & 0.219 & Poor & 0.971 * & 0.000 & Groups & \\
\hline & & & & Middle & 0.475 & 0.056 & & \\
\hline & Poor & 3.08 & 0.344 & Middle & -0.217 & 0.347 & Between & \\
\hline Corporate & & & 0.344 & High & -0.283 & 0.127 & Groups & 0.093 \\
\hline social & Middle & 3.30 & 0.322 & Poor & 0.217 & 0.347 & & \\
\hline responsibility & & & & High & -0.067 & 1.000 & Within & \\
\hline & High & 3.37 & 0.292 & $\begin{array}{l}\text { Poor } \\
\text { Middle }\end{array}$ & $\begin{array}{l}0.283 \\
0.067\end{array}$ & $\begin{array}{l}0.127 \\
1.000\end{array}$ & Groups & \\
\hline
\end{tabular}

* The mean difference is significant at the 0.05 level.

\section{Discussion}

\subsection{Overall Maturity Analysis of Supplier Management}

Generally, most contractors remain at a low level of maturity in supplier management; all dimensions stay at the third level, which is consistent with Broft's conclusion [9]. Kevin McCormak defined this level as "linked," contractors achieve close contact in business with supplier but do not realize supply chain integration. The evolution of maturity in operation efficiency (F2, 3.41) 
and procurement process $(\mathrm{F} 1,3.37)$ are higher than relationship coordination $(\mathrm{F} 3,3.11)$ and strategic alignment $(F 4,2.99)$. The result can be explained by following reasons: Firstly, most contractor focused on "hardware" aspect, such as operation management in construction implantation phase to achieve the project goal [42], due to operation management involves use of mechanical equipment, schedule of labors and materials, application of advanced technology, it needs more professional technical knowledge and skills. However, "software" aspect is ignored, such as relationship management and long-term performance. Second, the construction industry has long been criticized due to segmentation of supply chain. Due to the temporary nature of the project, it is difficult for participants to realize the diffusion of knowledge, sharing of information and distribution of benefits, so they are weak in relationship management and strategic management. Surprisingly, though findings indicate that "corporate social responsibility" (F5, 3.23) stands in the relatively higher level of maturity, environmental responsibility (such as "Implementation of environment regulation and standard" (F55, 2.53) and "Green design and cleaner technology" (F57, 2.74)) stay in the lower maturity level compared with social responsibility. It is suggested that most contractors have higher awareness of worker's occupational health and safety, because it has a directly impact on corporate image and project profits.

Furthermore, driving factors of supplier management were analyzed, such as "selection of suppliers" (F13, 3.76), "information sharing and communication" (F25, 3.50). Most contractors adopted multi-index qualitative evaluation and several contractors used advanced multi-index quantitative evaluation system. Most contractors are able to communicate with PC suppliers frequently, mainly through telephone, social network, BIM and meeting. "delivery time of PC" (F21, 3.59) also stands in a high level, it can be considered that most contractor pay more attention on project delivery time control, therefore they put higher requirement on supply time of PC. Once PC cannot be delivered to the construction site in time, the subsequent assembly process will be delayed. Idling of the workforce and equipment will increase construction cost [7]. There are also some factors that inhibit supplier management, such as "implementation of environment regulation and standard" (F55, 2.53), "green design and cleaner technology" (F57, 2.74), "flexibility to client demand" (F44, 2.76). It is demonstrated that most contractor are short-sighted, ignoring the continuous improvement and optimization of the supply chain or lacking motivation to improve. As for the green design and cleaner technology, due to the knowledge gap among participants, there is no reasonable mechanism to improve technology innovation under the background of low performance. On account of low level of standardization and modularization, most PCP cannot achieve flexibility to client demand.

\subsection{Multiple Comparison between Different Groups}

In terms of business scope, results indicate that single business contractor has higher maturity level than diversified business contractor except "corporate social responsibility" (F5, $p=0.375)$. The reason lies in that single contractors have established a complete supply chain integrating design, production and construction, they focused on their specific business scope and strengthen the relationship between participants. Importantly, partnership collaboration with PC suppliers transformed into a strategic level. However, prefabricated production is only a small part of business for diversified contactors, because they spread out business in many aspects. An integrated supply chain has not been achieved. They tend to pay more attention on operation management on-site. This conclusion is consistent with Ibrahim's research, he indicated that focused firms outperform both moderately and highly diversified firms on financial performance by studying the impact of product diversification on construction firm's performance in UK [56]. Results deviated from Oyewobi, who indicated that there are no statistically significant differences between the performance of diversified and undiversified firms based on South African construction companies [57]. In order to achieve continuous improvement in supplier management maturity, diversified business contractor should intensify strategic collaboration with PC suppliers. Nowadays, high capital costs impede some contractors to adopt prefabrication 
technology, collaboration in technology innovation and alignment in common goals can improve PCP performance [58].

As for procurement method, both EMPC and EPC contractors engage in overall contract and have higher maturity level than DBB contractors besides "corporate social responsibility" (F5). The outstanding difference between them is whether integrated PC supplier in their own business. EMPC contractors have integrated supply chain due to their own design company and PC factory. Supplier manufactured their product according to the drawings and transported them to the construction site in time according to the construction schedule. All partners attach more importance on information share and collaboration, strategic partnership could be formed [59]. Moreover, trust is directly conducive to interorganizational openness and communication, improving relationship alignment between contractor and suppliers in EPC projects [58]. EPC contractors need to order prefabricated production from specific suppliers; due to them not having their own PC factory, most EPC contractors established short-term collaboration. However, they have more experience in procurement and operation management. In general, the maturity level of "relationship coordination" (F3) and "strategy alignment" (F4) in EMPC contractor are slightly higher than that in EPC contractor. DBB contractor is charge with assembly process, so the relationship between supplier stayed a low maturity. We can also come to the conclusion that corporate social responsibility is irrelevant to the procurement method. In this research, the general contracting method is most suitable for PCP. Supplier should be integrated in the whole supply chain and should be involved in an early stage.

Findings indicated that construction experience has a big impact on SMM, which is in accordance with Fu's research, he considered that experienced contractor are more competitive than inexperience contractors, owing to project type familiarity and standardization of contract works packages [60]. When contractors are green hand in PCP, they can only achieve temporary cooperation on a single project with supplier, pay more attention to the performance of project operation rather than relationship management. With the increase of PCP, they accumulate more technology and management experience. Most contractor can establish long-term cooperation with suppliers in multiple projects. Interestingly, results manifest that construction experience have no direct relationship with corporate social responsibility.

\section{Conclusions}

This research attempts to develop a theoretical framework of supplier management maturity model including the dimensions of "procurement process," "operation efficiency," "relationship coordination" and "strategic alignment." Moreover, "corporate social responsibility" is integrated in the evaluation system. Five maturity levels are set to map the evolution of each indicator. A questionnaire survey was conducted towards construction firms listed in contractor directory in Yangtze River delta region in China. In general, the overall maturity level of supplier management is relatively low, as SMM is often seen as a project specific approach in construction rather than a central strategy such as in industries like aerospace and car manufacturing. In order to get full understanding of different groups of contractors for SMM, business scope, procurement method and PCP construction experience are further researched. Substantial results from the empirical study of 34 contractors conducted suggest the following:

- The general maturity of supplier management about general contractors is relatively low, most indicators stay in the third level, where contractors maintain close relation in business with supplier but do not achieve inter-organizational integration between suppliers.

- Maturity on relationship coordination and strategy alignment lag behind procurement management and operation efficiency.

- Contractors integrated in engineering, procurement and construction are superior to design-bid-build contractors in supplier management, especially in relationship coordination and strategic alignment. 
- Single business contractors have higher SMM than diversified ones. Construction experience is conductive to operation efficiency of supply chain.

- In terms of social responsibility, most contractors emphasize on workers safe and health, less attention on green technology and environmental protection. Moreover, there are no statistically significant differences in the performance of corporate social responsibility with business scope, procurement method and construction experience.

What is novel about this research lies that, firstly, the application domain of the supply chain maturity model has been expanded in PCP. In addition, the connotation of supply chain management between main contractor and suppliers is extended which integrate the implication of corporate social responsibility. Finally, the maturity model of PCP supply chain management is a dynamic evaluation tool which can provide a path of performance improvement for main contractor, it can also provide decision making support for owner to choose main contractor.

Three limitations in this research should be noted. First, the limitation of the surveyed contractor. This research focused on large contractors issued on PCP Contractor Directories in Yangtze River delta region, China, so the scope of the interviewees is limited. Besides, the universality of the results remains to be explored in other regions in China. Because of geographical advantage and ever-increasing economy in the surveyed area, a large number of contractors have emerged and other regions may be too far behind to repeat this advantage. Additionally, the assessment of SMM reflects the cognition of a contractor's personnel, thus the results can be affected by the characteristics of respondents. An improved method could be used to solve this problem by expending respondents of the same contractor or a two-way assessment between contractor and supplier. Moreover, there is no unified measurement standard to design the maturity level of each item for different dimensions, which weakened the reliability of comparison results.

Future research should expand data resources to test the availability of the maturity model. It is worth exploring the interactive effect of different dimensions of supplier management on project performance. Additionally, the evolution path of SMM in PCP could be studied over a longer time span from a dynamic perspective.

Author Contributions: K.L. came up with this research idea, conducted literature review, performed the theoretical framework model and wrote original draft. Y.S. contributed to data collection and participated in the data analysis. S.Z. provided some comments and supplemented the research framework.

Funding: This research received no external funding.

Acknowledgments: This research was substantially supported by The National Thirteenth-Five-year Research Program of China (2016YFC0701606). This study was partly supported by the Ministry of Housing and Urban-Rural Construction in Jiangsu province. The authors are grateful to the editors and reviewers of Sustainability for their valuable comments on this research.

Conflicts of Interest: The authors declare no conflict of interest. 


\section{Appendix A}

Table A1. Maturity model of supplier management.

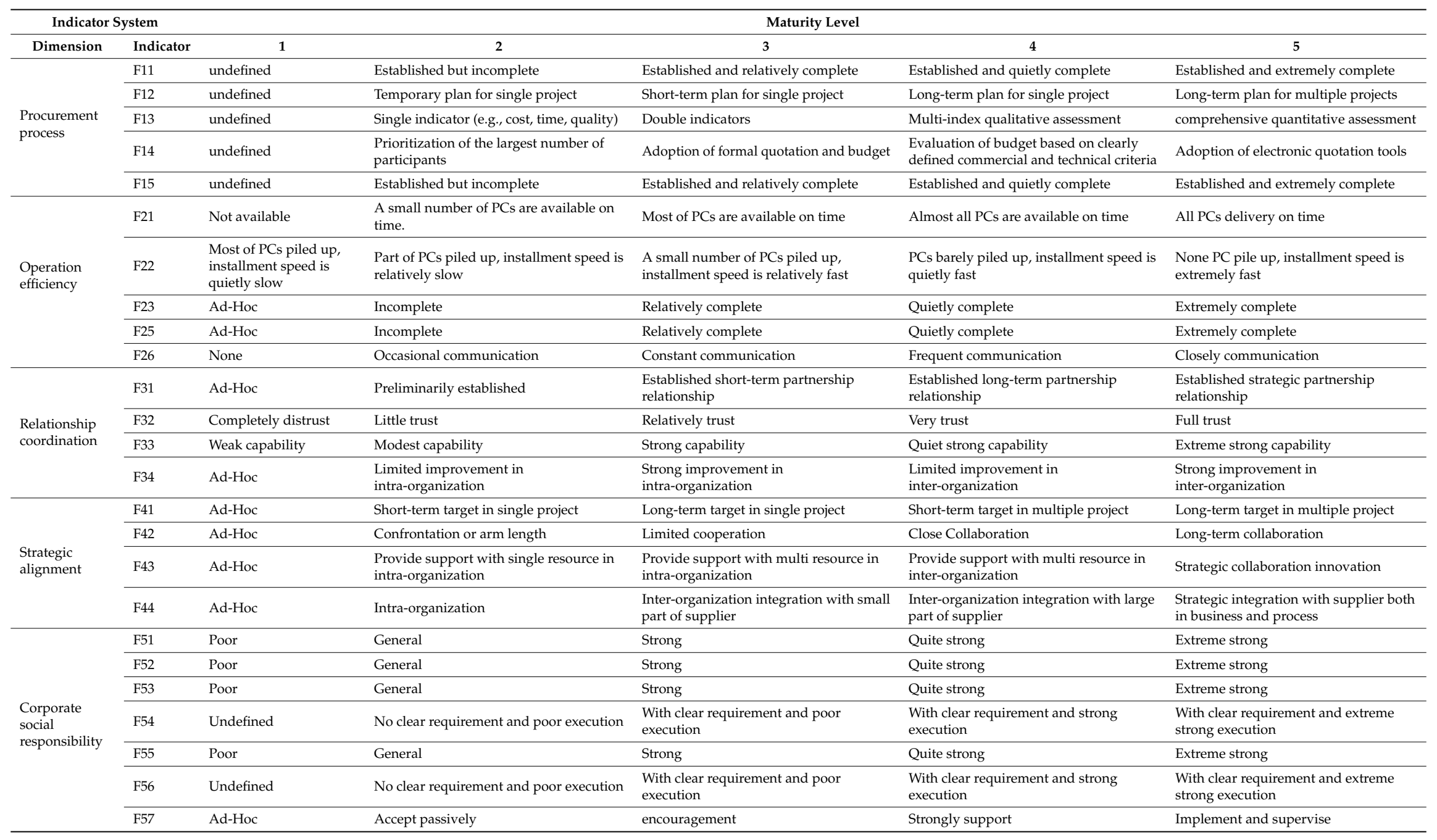




\section{References}

1. Pan, W.; Gibb, A.G.; Dainty, A.R.J. Strategies for Integrating the Use of Off-Site Production Technologies in House Building. J. Constr. Eng. Manag. 2012, 138, 1331-1340. [CrossRef]

2. Mostafa, S.; Chileshe, N.; Abdelhamid, T. Lean and agile integration within offsite construction using discrete-event simulation: A systematic literature review. Constr. Innov. 2016, 16, 483-525. [CrossRef]

3. Zhai, X.; Reed, R.; Mills, A. Factors impeding the offsite production of housing construction in China: An investigation of current practice. Constr. Manag. Econ. 2014, 32, 40-52. [CrossRef]

4. Masood, R.; Gonzalez, V.; Lim, J.B.P. Value Stream Mapping-a Case Study of Cold-Formed Steel House Framing for Offsite Manufacturing Supply Chain. In Proceedings of the 25th Annual Conference of the International Group for Lean Construction, Heraklion, Greece, 9-12 July 2017.

5. Arashpour, M.; Wakefield, R.; Lee, E.W.M.; Chan, R.; Hosseini, M.R. Analysis of interacting uncertainties in on-site and off-site activities: Implications for hybrid construction. Int. J. Proj. Manag. 2016, 34, 1393-1402. [CrossRef]

6. Lith, J.V.; Voordijk, H.; Matos Castano, J.; Vos, B. Assessing maturity development of purchasing management in construction. Benchmarking Int. J. 2015, 22, 1033-1057. [CrossRef]

7. Arashpour, M.; Abbasi, B.; Hosseini, M.R.; Yang, R. Integrated management of on-site, coordination and off-site uncertainty: Theorizing risk analysis within a hybrid project setting. Int. J. Proj. Manag. 2017, 35, 647-655. [CrossRef]

8. Sariola, R. Utilizing the innovation potential of suppliers in construction projects. Constr. Innov. $2018,18$. [CrossRef]

9. Broft, R.; Badi, S.M.; Pryke, S. Towards supply chain maturity in construction. Built Environ. Proj. Asset Manag. 2016, 6, 187-204. [CrossRef]

10. Correia, E.; Carvalho, H.; Azevedo, S.G.; Govindan, K. Maturity Models in Supply Chain Sustainability: A Systematic Literature Review. Sustainability 2017, 9, 64. [CrossRef]

11. Tontini, G.; Carvalho, L.C.D.; Tomarevski, V. Maturity model of procurement and supply management in small and medium-size enterprises: A benchmarking of hospitals and metal-mechanic companies. Int. J. Qual. Serv. Sci. 2016, 8, 315-333. [CrossRef]

12. Meng, X.; Sun, M.; Jones, M. Maturity Model for Supply Chain Relationships in Construction. J. Manag. Eng. 2011, 27, 97-105. [CrossRef]

13. Naoum, S.G.; Egbu, C. Modern selection criteria for procurement methods in construction. Int. J. Manag. Proj. Bus. 2016, 9, 309-336. [CrossRef]

14. Srai, J.S.; Alinaghian, L.S.; Kirkwood, D.A. Understanding sustainable supply network capabilities of multinationals: A capability maturity model approach. Proc. Inst. Mech. Eng. Part B J. Eng. Manuf. 2013, 227, 595-615. [CrossRef]

15. Segerstedt, A.; Olofsson, T. Supply chains in the construction industry. Supply Chain Manag. 2010, 15, 347-353. [CrossRef]

16. Koolwijk, J.S.J.; van Oel, C.J.; Wamelink, J.W.F.; Vrijhoef, R. Collaboration and Integration in Project-Based Supply Chains in the Construction Industry. J. Manag. Eng. 2018, 34. [CrossRef]

17. Stroebele, B.S.; Kiessling, A.J.; Zhang, J. Impact Analysis of Complexity Drivers in the Supply Chain of Prefabricated Houses. J. Manag. Strat. 2017, 8. [CrossRef]

18. Naim, M.; Barlow, J. An innovative supply chain strategy for customized housing. Constr. Manag. Econ. 2003, 21, 593-602. [CrossRef]

19. Eriksson, P.E. Improving construction supply chain collaboration and performance: A lean construction pilot project. Supply Chain Manag. 2010, 15, 394-403. [CrossRef]

20. Anvari, B.; Angeloudis, P.; Ochieng, W.Y. A multi-objective GA-based optimisation for holistic Manufacturing, transportation and Assembly of precast construction. Autom. Constr. 2016, 71, $226-241$. [CrossRef]

21. Khalili, A.; Chua, D.K. Integrated Prefabrication Configuration and Component Grouping for Resource Optimization of Precast Production. J. Constr. Eng. Manag. 2014, 140. [CrossRef]

22. Han, Y.; Skibniewski, M.J.; Wang, L. A Market Equilibrium Supply Chain Model for Supporting Self-Manufacturing or Outsourcing Decisions in Prefabricated Construction. Sustainability 2017, 9, 2069. [CrossRef] 
23. Wang, Z.J.; Hu, H. Improved Precast Production-Scheduling Model Considering the Whole Supply Chain. J. Comput. Civ. Eng. 2017, 31, 04017013. [CrossRef]

24. Arashpour, M.; Wakefield, R.; Blismas, N.; Minas, J. Optimization of process integration and multi-skilled resource utilization in off-site construction. Autom. Constr. 2015, 50, 72-80. [CrossRef]

25. Olearczyk, J.; Al-Hussein, M.; Bouferguene, A. Evolution of the crane selection and on-site utilization process for modular construction multilifts. Autom. Constr. 2014, 43, 59-72. [CrossRef]

26. Arashpour, M.; Wakefield, R.; Abbasi, B.; Lee, E.W.M.; Minas, J. Off-site construction optimization: Sequencing multiple job classes with time constraints. Autom. Constr. 2016, 71, 262-270. [CrossRef]

27. Zhai, Y.; Zhong, R.Y.; Li, Z.; Huang, G. Production lead-time hedging and coordination in prefabricated construction supply chain management. Int. J. Prod. Res. 2016, 55, 3984-4002. [CrossRef]

28. Hofman, E.; Voordijk, H.; Halman, J. Matching supply networks to a modular product architecture in the house-building industry. Build. Res. Inf. 2009, 37, 31-42. [CrossRef]

29. Seuring, S.; Kache, F. Linking collaboration and integration to risk and performance in supply chains via a review of literature reviews. Supply Chain Manag. 2014, 19, 664-682.

30. Čuš-Babič, N.; Rebolj, D.; Nekrep-Perc, M.; Podbreznik, P. Supply-chain transparency within industrialized construction projects. Comput. Ind. 2014, 65, 345-353. [CrossRef]

31. Mccormack, K.; Ladeira, M.B. Supply chain maturity and performance in Brazil. Supply Chain Manag. 2008, 13, 272-282. [CrossRef]

32. Crosby, P.B. Quality Is Free: The Art of Making Quality Certain; New American Library: New York, NY, USA, 1979.

33. Paulk, M.C. The capability maturity model for software: A tutorial. Softw. Qual. J. 1994, 2, 49-88.

34. Organizational Project Management Maturity Model. Available online: https://www.pmi.org/ pmbok-guide-standards/foundational/organizational-pm-maturity-model-opm3-third-edition (accessed on 27 August 2018).

35. Lambert, D.M.; García-Dastugue, S.J.; Croxton, K.L. An Evaluation of Process-oriented Supply Chain Management Frameworks. J. Bus. Logist. 2005, 26, 25-51. [CrossRef]

36. Reay, J.H.; Colaianni, A.J.; Harleston, E.F.; Maletic, A.; Marcus, J.G. Logistics Maturity Evaluator. Available online: https:/ / www.researchgate.net/publication/235138861_Logistics_Maturity_Evaluator (accessed on 27 August 2018).

37. Iii, A.L.; Mccormack, K. The development of a supply chain management process maturity model using the concepts of business process orientation. Supply Chain Manag. 2004, 9, 272-278.

38. Frödell, M. Criteria for achieving efficient contractor-supplier relations. Eng. Constr. Arch. Manag. 2011, 18, 381-393. [CrossRef]

39. Xue, H.; Zhang, S.; Su, Y.; Wu, Z. Factors Affecting the Capital Cost of Prefabrication-A Case Study of China. Sustainability 2017, 9, 1512. [CrossRef]

40. Jääskeläinen, A.; Thitz, O. Prerequisites for performance measurement supporting purchaser-supplier collaboration. Benchmarking Int. J. 2018, 25, 120-137. [CrossRef]

41. Seth, D.; Nemani, V.S.R.K.; Pokharel, S.; Al Sayed, A.Y. Impact of competitive conditions on supplier evaluation: A construction supply chain case study. Prod. Plan. Control 2017, 217-235. [CrossRef]

42. Bemelmans, J.; Voordijk, H.; Vos, B.; Buter, J. Assessing Buyer-Supplier Relationship Management: Multiple Case-Study in the Dutch Construction Industry. J. Constr. Eng. Manag. 2012, 138, 163-176. [CrossRef]

43. Mohammad, M.F.; Shukor, A.S.A.; Mahbub, R.; Halil, F.M. Challenges in the Integration of Supply Chains in IBS Project Environment in Malaysia. Procedia Soc. Behav. Sci. 2014, 153, 44-54. [CrossRef]

44. Petrovic-Lazarevic, S. The development of corporate social responsibility in the Australian construction industry. Constr. Manag. Econ. 2008, 26, 93-101. [CrossRef]

45. Loosemore, M.; Lim, B.T.H. Linking corporate social responsibility and organizational performance in the construction industry. Constr. Manag. Econ. 2017, 35, 90-105. [CrossRef]

46. Bemelmans, J.; Voordijk, H.; Vos, B. Designing a tool for an effective assessment of purchasing maturity in construction. Benchmarking Int. J. 2013, 20, 342-361. [CrossRef]

47. Aloini, D.; Dulmin, R.; Mininno, V.; Ponticelli, S. Supply chain management: A review of implementation risks in the construction industry. Bus. Process Manag. J. 2012, 18, 735-761. [CrossRef]

48. Xue, H.; Zhang, S.; Su, Y.; Wu, Z.; Yang, R.J. Effect of stakeholder collaborative management on off-site construction cost performance. J. Clean. Prod. 2018, 184, 490-502. [CrossRef] 
49. Nahmens, I.; Ikuma, L.H. Effects of Lean Construction on Sustainability of Modular Homebuilding. J. Arch. Eng. 2012, 18, 155-163. [CrossRef]

50. Jaillon, L.; Poon, C.S. Sustainable construction aspects of using prefabrication in dense urban environment: A Hong Kong case study. Constr. Manag. Econ. 2008, 26, 953-966. [CrossRef]

51. Kamali, M.; Hewage, K. Development of performance criteria for sustainability evaluation of modular versus conventional construction methods. J. Clean. Prod. 2017, 142, 3592-3606. [CrossRef]

52. Rasch, D.; Teuscher, F.; Guiard, V. How robust are tests for two independent samples? J. Stat. Plan. Inference 2007, 137, 2706-2720. [CrossRef]

53. Surhone, L.M. Welch's $t$ Test. Available online: https://www.researchgate.net/publication/301292970_ Welch\%27s_t_test (accessed on 27 August 2018).

54. Howell, D.C. Statistical Methods for Psychology; Cengage Learning: Boston, MA, USA, 2012.

55. Copeland, K.A.F. Design and Analysis of Experiments, 5th ed.; John Wiley and Sons: Hoboken, NJ, USA, 2001.

56. Ibrahim, Y.M.; Kaka, A.P. The impact of diversification on the performance of UK construction firms. J. Financ. Manag. Prop. Constr. 2007, 12, 73-86. [CrossRef]

57. Oyewobi, L.O.; Windapo, A.O.; Cattell, K.S. Impact of business diversification on South African construction companies' corporate performance. J. Financ. Manag. Prop. Constr. 2013, 18, 110-127. [CrossRef]

58. Shen, W.; Tang, W.; Wang, S.; Duffield, C.F.; Hui, F.K.P.; You, R. Enhancing Trust-Based Interface Management in International Engineering-Procurement-Construction Projects. J. Constr. Eng. Manag. 2017, 143, 04017061. [CrossRef]

59. Micheli, G.J.; Cagno, E. The role of procurement in performance deviation recovery in large EPC projects. Int. J. Eng. Bus. Manag. 2016, 8. [CrossRef]

60. Fu, W.K.; Drew, D.S.; Lo, H.P. Competitiveness of Inexperienced and Experienced Contractors in Bidding. J. Constr. Eng. Manag. 2003, 129, 388-395. [CrossRef]

(C) 2018 by the authors. Licensee MDPI, Basel, Switzerland. This article is an open access article distributed under the terms and conditions of the Creative Commons Attribution (CC BY) license (http://creativecommons.org/licenses/by/4.0/). 